\title{
Gestational age specific anthropometric percentile charts of newborns at Kathmandu Medical College Teaching Hospital
}

\section{Manandhar SR', Manandhar DS²}

'Sunil Raja Manandhar, Assistant Professor; ${ }^{2}$ Dharma Sharna Manandhar, Former Professor and Head; Department of Paediatrics, Kathmandu Medical College Teaching Hospital, Kathmandu, Nepal

\begin{abstract}
Background: A gestational age specific birth weight, length and head circumference centile chart will help to identify intrauterine growth of a baby. Since the first published gestational age specific anthropometric study done in Nepal by Manandhar DS et al in 1993-94, there have been significant changes in socioeconomic conditions with improved health indicators. This study was done for identifying any changes in anthropometric measurements of the newborns born at Kathmandu Medical College Teaching Hospital (KMCTH).

Objectives: To produce gestational age specific birth weight, length and head circumference centile charts of the newborn babies born at KMCTH and to calculate incidence of low birth weight (LBW) babies at KMCTH.

Methods: This is a cross sectional observational study. Study was done at labour room, operation theatre, special care baby unit and postnatal wards of KMCTH. Study period was from $18^{\text {th }}$ Aug 2011 to $28^{\text {th }}$ Nov 2012 (15 months duration). Within 24 hours of birth, baby's weight, length and head circumference were measured by medical officers and post graduate Residents of the Paediatrics Department. Mother's weight, height and ethnicity were also recorded. Maturity of the baby was assessed by maternal history and corroborated by using modified Ballard score and Obstetric USG (Ultra sonogram) findings. Data were entered in excel database programme and later transferred into SPSS (Statistical package of social science) 16. Mean, standard deviation, range and percentiles values at different gestational age specific groups were calculated.

Results: A total of 2029 live babies without gross congenital malformations were included in this study, among which 57\% (1154) were male. While analyzing maturity assessment, 89.1\% (1808) were term, 8.7\% (176) were preterm and 2.2 $\%$ (45) babies were post term. Mean birth weight at 40 weeks of gestation was $3.10 \mathrm{~kg}$ with Standard Deviation (SD) of $0.4 \mathrm{~kg}$, mean head circumference was $34.0 \mathrm{~cm}(\mathrm{SD} 1.2 \mathrm{~cm}$ ) and mean length was $49.2 \mathrm{~cm}(\mathrm{SD} 2.2 \mathrm{~cm})$. Out of 2029 babies, $16.2 \%$ (328) babies were low birth weight (LBW) and $1.4 \%$ (28) babies weighed $>4 \mathrm{~kg}$.

Conclusion: Percentile charts of newborns will help to assess the intrauterine growth of babies. Further more studies of these percentile charts will help to produce national level percentile charts of newborns of Nepal.
\end{abstract}

Key words: Anthropometric measurements, Gestational age specific percentile charts

\section{INTRODUCTION}

T Nepal, more than $63 \%$ of the deliveries take place at home ${ }^{1}$ where birth weight is often not recorded. In developing countries, low birth weight (LBW) $<2500$ $g$ accounts for $60-80 \%$ of neonatal deaths ${ }^{2}$. Neonatal anthropometric parameters are significant predictive factors of neonatal morbidity and mortality. Birth weight is an important determinant of infant's survival and future development ${ }^{3}$. Prevalence of LBW in Nepal

Address for correspondence

Dr. Sunil Raja Manandhar

Assistant Professor

Department of Paediatrics

Kathmandu Medical College Teaching Hospital,

Kathmandu, Nepal

Email: drsunilraja@gmail.com was reported as $27 \% \%^{4}$. A gestational age specific birth weight, length and head circumference centile chart will help to identify small for date babies and will also help in following the growth of a baby born before term ${ }^{5}$. So far, there are very few studies done in Nepal regarding gestational age specific birth weight, length and head circumference percentile charts of Nepalese babies.

A hospital based study at Paropakar Maternity hospital, Kathmandu, Nepal in 1997 by Manandhar DS et al ${ }^{6}$ found low birth weight $(<2.5 \mathrm{~kg})$ in $32 \%$ of the newborns, mean birth weight of $2660 \mathrm{~g}$ (standard deviation, SD 80 g) and mean head circumference $32.6 \mathrm{~cm}(S D 1.3 \mathrm{~cm})$. A hospital based study done at Kathmandu Medical College Teaching Hospital (KMCTH), Kathmandu in 2003 by Manandhar $\mathrm{K}$ et $\mathrm{al}^{3}$ found that the mean birth 
weight of term babies was $3050 \mathrm{~g}$ (SD $41 \mathrm{~g}$ ), mean length $49 \mathrm{~cm}(S D 2.2 \mathrm{~cm})$ and mean head circumference was $33.8 \mathrm{~cm}$ (SD $1.4 \mathrm{~cm}$ ). Similarly, another hospital based study at Western Zonal Hospital, Pokhara, Nepal by Sreeramareddy CT et $\mathrm{al}^{2}$ found that the mean birth weight was $3029 \mathrm{~g}$ (SD $438 \mathrm{~g}$ ) and 8.5\% newborns were low birth weight.

The objective of this study is to generate a gestational age specific birth weight, length and head circumference percentile charts of the babies born at KMCTH and to calculate incidence of low birth weight at KMCTH.

\section{METHODS}

This is a cross sectional study. The hospital permission was taken to carry out this research. Anthropometric measurements were taken at the labour room, operation theatre, special care baby unit and postnatal wards of Kathmandu Medical College Teaching Hospital (KMCTH). The study period was from $18^{\text {th }}$ August 2011 to $30^{\text {th }}$ November 2012 (15.5 months). A total of 2029 live newborn babies without gross congenital malformations were included. Within 24 hours of age, routine examination of newborn babies and birth weight, length and head circumference were measured by post graduate residents and medical officers of Paediatrics Department, KMCTH under close supervision by the principal author. Naked babies' weight were measured by an electronic weighing scale (Salter, UK) which has a sensitivity of 10 grams. Length was measured by two persons using a Kiddimeter (Child Growth Foundation, UK) which can read up to $10 \mathrm{~mm}$. Head circumference was measured by non-stretchable paper measuring tape (Allegiance infant measuring tape, USA) which can read up to $1 \mathrm{~mm}$. Maternal weight, height and ethnicity were also assessed. Maternal weight and height were measured by Stadiometer and maternal haemoglobin was obtained by Coulter machine. Data were entered in excel database programme and later transferredinto SPSS (Statistical package of social science) 16. Mean, median; mode, standard deviation, range and percentiles values at different gestational age specific groups were calculated. Percentiles values were obtained by using Tukey's Hinges method in statistical analysis SPSS 16 version. $10^{\text {th }}, 50^{\text {th }}$ and $90^{\text {th }}$ centile values were obtained for different gestational age groups.

Preterm baby is defined as any neonate born before 37 weeks ( $<259$ days) of pregnancy irrespective of birth weight. Similarly term is defined as any neonate born between 37 weeks and <42 weeks ( 259 - 293 days) of pregnancy irrespective of birth weight, whereas postterm baby is defined as a neonate born at gestation age of 42 weeks or more (294 days or more) irrespective of the birth weight ${ }^{7}$.

Stillbirths, multiple births, gross congenital malformation and hydrops were excluded. Maturity of the baby was assessed by maternal history and corroborated by using modified Ballard score, and Obstetric USG findings.

\section{RESULTS}

Total of 2029 live born babies without gross congenital malformations were included in this study. Among those, $57 \%$ (1154) were male and $43 \%$ (875) were female, which is shown in table 1 . While analyzing maturity assessment, 89.1\% (1808) were term, 8.7\% (176) were preterm and $2.2 \%$ (45) babies were post-term. Mean birth weight ( $50^{\text {th }}$ centile) at 40 wks gestation was (mean \pm SD) $3.10 \pm 0.46 \mathrm{~kg}$, mean head circumference was $34.16 \pm 1.29 \mathrm{~cm}$ and mean length was $49.33 \pm 2.26 \mathrm{~cm}$. Out of 2029 babies, $82.5 \%$ (1673) babies were of normal weight, $16.1 \%$ (328) babies were low birth weight and $1.4 \%$ (28) babies weighed $>4 \mathrm{~kg}$.

Percentile charts of $10^{\text {th }}, 50^{\text {th }}$ and $90^{\text {th }}$ centile for birth weight, length and head circumference according to gestational age were generated. According to this centile chart, at 40 weeks gestational age, mean birth weight was $3.1 \mathrm{~kg}, \mathrm{HC}$ was $34 \mathrm{~cm}$ and length was $49.2 \mathrm{~cm}$ which are depicted in Table 2, 3 and 4 respectively. Since number of newborn babies was small in each of 25 to 32 weeks and 43 weeks gestational age groups (Table 1), percentile values were not calculated for these groups. While analyzing maternal characteristics, mother's mean weight was $59.73 \pm 8.3 \mathrm{~kg}$, mean BMl was $25.37 \pm 3.85$ $\mathrm{kg} / \mathrm{m}^{2}$ and mean $\mathrm{Hb}$ was $11.93 \pm 1.34 \mathrm{gm} / \mathrm{dl}$, which are shown in Table 5. 
Table 1: Distribution of newborns babies according gestational age and sex.

\begin{tabular}{|cccc|}
\hline Gestation age (weeks) & Female & Male & Total \\
\hline 25 & 2 & 0 & 2 \\
\hline 26 & 0 & 1 & 1 \\
\hline 28 & 0 & 5 & 5 \\
\hline 29 & 1 & 3 & 4 \\
\hline 30 & 1 & 2 & 3 \\
\hline 31 & 1 & 2 & 3 \\
\hline 32 & 4 & 8 & 12 \\
\hline 33 & 4 & 15 & 19 \\
\hline 34 & 17 & 17 & 34 \\
\hline 35 & 18 & 16 & 34 \\
\hline 36 & 15 & 44 & 59 \\
\hline 37 & 77 & 128 & 205 \\
\hline 38 & 182 & 266 & 448 \\
\hline 39 & 186 & 273 & 459 \\
\hline 40 & 285 & 298 & 583 \\
\hline 41 & 59 & 54 & 113 \\
\hline 43 & 18 & 17 & 35 \\
\hline
\end{tabular}

Table 2: Percentile Chart: weight for age (kg)

\begin{tabular}{lcccccccccc}
\hline $\begin{array}{l}\text { Gestation week } \\
\text { (Observations) }\end{array}$ & $\mathbf{3 3}$ & $\mathbf{3 4}$ & $\mathbf{3 5}$ & $\mathbf{3 6}$ & $\mathbf{3 7}$ & $\mathbf{3 8}$ & $\mathbf{3 9}$ & $\mathbf{4 0}$ & $\mathbf{4 1}$ & $\mathbf{4 2}$ \\
$10^{\text {th }}$ centile & 1.47 & $\mathbf{( 3 4 )}$ & $\mathbf{( 3 4 )}$ & $\mathbf{( 5 9 )}$ & $\mathbf{( 2 0 5 )}$ & $\mathbf{( 4 4 8 )}$ & $\mathbf{( 4 5 9 )}$ & $\mathbf{( 5 8 3 )}$ & $\mathbf{( 1 1 3 )}$ & $\mathbf{( 3 5 )}$ \\
\hline $50^{\text {th }}$ centile & 1.82 & 1.97 & 2.27 & 2.54 & 2.75 & 3.00 & 3.00 & 3.10 & 3.15 & 3.20 \\
\hline $90^{\text {th }}$ centile & 2.52 & 2.72 & 2.89 & 3.32 & 3.32 & 3.53 & 3.60 & 3.65 & 3.61 & 3.76 \\
\hline
\end{tabular}

Table 3: Percentile Chart: Head Circumference for age (cm)

\begin{tabular}{lcccccccccc}
\hline Gestation week & $\mathbf{3 3}$ & $\mathbf{3 4}$ & $\mathbf{3 5}$ & $\mathbf{3 6}$ & $\mathbf{3 7}$ & $\mathbf{3 8}$ & $\mathbf{3 9}$ & $\mathbf{4 0}$ & $\mathbf{4 1}$ & $\mathbf{4 2}$ \\
(Observations) & $\mathbf{( 1 8 )}$ & $\mathbf{( 3 4 )}$ & $\mathbf{( 3 4 )}$ & $\mathbf{( 5 9 )}$ & $\mathbf{( 2 0 5 )}$ & $\mathbf{( 4 4 8 )}$ & $\mathbf{( 4 5 9 )}$ & $\mathbf{( 5 8 3 )}$ & $\mathbf{( 1 1 3 )}$ & $\mathbf{( 3 5 )}$ \\
\hline $10^{\text {th }}$ centile & 28.1 & 28.5 & 28.5 & 30.0 & 31.4 & 32.4 & 32.5 & 32.8 & 32.5 & 32.9 \\
\hline $50^{\text {th }}$ centile & 30.5 & 31.0 & 32.0 & 33.0 & 34.0 & 34.0 & 34.0 & 34.0 & 34.0 & 34.0 \\
\hline $90^{\text {th }}$ centile & 33.3 & 33.7 & 34.0 & 35.0 & 35.5 & 35.8 & 36.0 & 36.0 & 35.1 & 35.1 \\
\hline
\end{tabular}

Table 4: Percentile Chart: Length for age (cm)

\begin{tabular}{lcccccccccc}
\hline Gestation week & $\mathbf{3 3}$ & $\mathbf{3 4}$ & $\mathbf{3 5}$ & $\mathbf{3 6}$ & $\mathbf{3 7}$ & $\mathbf{3 8}$ & $\mathbf{3 9}$ & $\mathbf{4 0}$ & $\mathbf{4 1}$ & $\mathbf{4 2}$ \\
(Observations) & $\mathbf{( 1 8 )}$ & $\mathbf{( 3 4 )}$ & $\mathbf{( 3 4 )}$ & $\mathbf{( 5 9 )}$ & $\mathbf{( 2 0 5 )}$ & $\mathbf{( 4 4 8 )}$ & $\mathbf{( 4 5 9 )}$ & $\mathbf{( 5 8 3 )}$ & $\mathbf{( 1 1 3 )}$ & $\mathbf{( 3 5 )}$ \\
\hline $10^{\text {th }}$ centile & 41.8 & 42.7 & 40.7 & 44.0 & 45.5 & 46.0 & 47.0 & 47.0 & 46.0 & 46.8 \\
\hline $50^{\text {th }}$ centile & 45.0 & 46.0 & 46.5 & 48.0 & 48.9 & 49.0 & 49.0 & 49.2 & 49.0 & 49.7 \\
\hline $0^{\text {th }}$ centile & 47.8 & 48.4 & 49.2 & 50.1 & 51.2 & 51.8 & 51.5 & 52.0 & 51.5 & 52.5 \\
\hline
\end{tabular}

Table 5: Maternal Characteristics of this study

\begin{tabular}{lcc}
\hline Variables & Mean \pm SD & Range \\
\hline Weight $(\mathrm{kg})$ & $59.73 \pm 8.36$ & $40-100 \mathrm{~kg}$ \\
\hline Height $(\mathrm{cm})$ & $153.92 \pm 6.5$ & $120-177.5 \mathrm{~cm}$ \\
$\mathrm{BMl}\left(\mathrm{kg} / \mathrm{m}^{2}\right)$ & $25.37 \pm 3.85$ & $14.2-48.6 \mathrm{~kg} / \mathrm{m}^{2}$ \\
$\mathrm{Hb}(\mathrm{gm} / \mathrm{dl})$ & $11.93 \pm 1.34$ & $9-17 \mathrm{gm} / \mathrm{dl}$ \\
\hline
\end{tabular}


Table 6: Comparison of selected birth weight percentile among two studies.

\begin{tabular}{|c|c|c|c|c|c|c|c|c|c|c|}
\hline \multirow[b]{2}{*}{ Study site } & \multirow{2}{*}{$\begin{array}{l}\text { Sample } \\
\text { size }\end{array}$} & \multicolumn{3}{|c|}{ 33weeks } & \multicolumn{3}{|c|}{36 weeks } & \multicolumn{3}{|c|}{40 weeks } \\
\hline & & $\begin{array}{c}10^{\text {th }} \\
\text { Centile }\end{array}$ & $\begin{array}{c}50^{\text {th }} \\
\text { Centile }\end{array}$ & $\begin{array}{c}90^{\text {th }} \\
\text { Centile }\end{array}$ & $\begin{array}{c}10^{\text {th }} \\
\text { Centile }\end{array}$ & $\begin{array}{l}50^{\text {th }} \\
\text { Centile }\end{array}$ & $\begin{array}{c}90^{\text {th }} \\
\text { Centile }\end{array}$ & $\begin{array}{c}10^{\text {th }} \\
\text { Centile }\end{array}$ & $\begin{array}{c}50^{\text {th }} \\
\text { Centile }\end{array}$ & $\begin{array}{c}90^{\text {th }} \\
\text { Centile }\end{array}$ \\
\hline KMCTH 2011 (Present study) & 2029 & 1.47 & 1.82 & 2.52 & 1.80 & 2.54 & 3.32 & 2.50 & 3.10 & 3.65 \\
\hline $\begin{array}{l}\text { Paropakar Maternity Hospital } 2010 \\
\text { By Aryal DR et al }\end{array}$ & 9710 & 1.52 & 1.85 & 2.19 & 2.06 & 2.47 & 2.91 & 2.55 & 3.02 & 3.52 \\
\hline
\end{tabular}

\section{DISCUSSION}

Prevalence of LBW in India was reported to be $30 \%^{8}$ and incidence of LBW in tertiary centers of India 32.8\% ${ }^{9}$. A study done by Yagnik CS et $\mathrm{al}^{10}$ found that the mean birth weight of newborns in Pune, India was $2666 \mathrm{~g}$. Matthai $\mathrm{M}$ et $\mathrm{al}^{11}$ at Christian Medical College, Vellore, India postulated that birth weight of newborns was related to the height of the mother. They found that the mean birth weight of infants born to women with a height of $150-158 \mathrm{~cm}$ was $2945 \pm 516 \mathrm{~g}$ as compared to $2847 \mathrm{SD} \pm 480 \mathrm{~g}$ to mothers with height $<150 \mathrm{~cm}$.

A study done in Bangladesh by Dhar B et al ${ }^{12}$ in Public maternity hospital, Dhaka found that mean birth-weight was $2889 \pm 468$ gms and $15.1 \%$ babies were low-birthweight. Male babies $(2951 \pm 471 \mathrm{~g})$ are slightly heavier than female babies $(2813 \pm 454 \mathrm{~g})$ and also found that $42.7 \%$ babies are in between $2.5-3 \mathrm{~kg}$. A similar study done by Haque $\mathrm{F}$ et $\mathrm{al}^{13}$ in Bangladesh found that mean birth weight was $2679 \pm 431 \mathrm{~g}$ and male babies ( $2692 \pm$ $409 \mathrm{~g})$ are slightly heavier than female $(2665 \pm 452 \mathrm{~g})$.

A hospital based study done by Najmi $\mathrm{SR}^{14}$ in Fatima Jinnah Medical College, Lahore reported mean birth weight of $2.91 \mathrm{~kg}$. Among them, 19\% were low birth weight, $78 \%$ babies were in between 2.5 to $4 \mathrm{~kg}$ and three percent of neonates weighed above $4 \mathrm{~kg}$.

Following the first comprehensive anthropometric study done in Nepal about 18 years ago by DS Manandhar et $\mathrm{al}^{5}$, there have been significant changes in socioeconomic conditions with better health indicators at urban areas of Nepal'. In this study, mean birth weight of the babyat 40 weeks ( $3100 \mathrm{gms}$ ) is higher than the national figure i.e. $2780 \mathrm{~g}^{15}$ and is significantly higher than the first published gestational age specific birth weight percentile chart from the Paropakar Maternity Hospital, Kathmandu in 1993- 94 by Manandhar DS et al ( 2800 $\mathrm{g})^{5}$. Maternal mean weight in that study ${ }^{6}$ was $49.4 \pm 6 \mathrm{~kg}$ and mean BMI was $21.31 \mathrm{~kg} / \mathrm{m}^{2}$ where as in this study at $\mathrm{KMCTH}$, mean maternal weight was $59.73 \pm 8.36 \mathrm{~kg}$ and maternal mean BMI was $25.37 \pm 3.85 \mathrm{~kg} / \mathrm{m}^{2}$ showing a significant increase in maternal nutrition within these 20 year period. A recent study done at the same hospital in 2010 by Aryal DR et al ${ }^{15}$ also showed increased birth weight (mean birth weight was 3023 gms), which are depicted in Table 6 showing comparison among two hospitals in birth weight at 33 weeks, 36 weeks and 40 weeks respectively.

Similarly, a hospital based study done at the western zonal hospital, Pokhara in Nepal by Sreeramareddy CT et $\mathrm{al}^{2}$ also found a mean birth weight of $3029 \pm 438 \mathrm{~g}$.

Quite a significant number of mothers in the 199394 study at Paropakar Maternity Hospital were primi, young, undernourished poor carpet workers coming from outside Kathmandu valley where as in this study and the study reported by Aryal DR et al, most of the mothers are from urban regions of Kathmandu valley with better educational background and had received better antenatal care. Overall better anthropometric values seen in the newborns in the present study could be due to overall improvement in maternal nutrition in the country in general and particularly among mothers who delivered at KMCTH. This could be a reflection of better maternal nutrition and increase in maternal socioeconomic condition in Kathmandu valley area.

Limitation of this study: As the newborn babies are few in numbers among 25 to 32 weeks and 43 weeks of gestational age, percentile values could not be reliably calculated for these groups.

\section{CONCLUSION}

This study showed a significant increase in birth weight, and decrease in the incidence of low birth weight at Kathmandu Medical College Teaching Hospital. These anthropometric percentile charts of newborn babies of Kathmandu Medical College will help to produce national level percentile charts of newborns of Nepal, if meta-analysis of anthropometric measurements from different regions of Nepal were done.

\section{ACIKNOWLEDGEMENT}

Our sincere acknowledgment to all PG residents and medical officers of Paediatrics Department for their contribution in anthropometric measurements. 


\section{REFERENCES}

1. Population division, Ministry of Health and Population (MoHP), Government of Nepal. Infant and child mortality. In: New ERA and Macro International Inc. Nepal Demographic and Health Survey (NDHS) 2011. Kathmandu: Ministry of Health and Population, New ERA, and Macro International Inx: 2011.p 125.

2. Sreeramareddy CT, Chuni N, Patil R, Singh D, Shakya B. Anthropometric surrogates to identify low birth weight Nepalese newborns: a hospital-based study. BMC Pediatrics. 2008;8:16. doi:10.1186/1471-24318-16.

3. Manandhar K, Manandhar DS, Baral MR. One year follow up study of term babies born at Kathmandu Medical College Teaching Hospital. Kathmandu Univ Med J. 2004;4(8):286-90.

4. MIRA. Low Birth Weight prevalence and associated factors in four regions of Nepal. (A multi- hospital based study). UNICEF. 2000 Jun.

5. Manandhar DS, Osrin D, Malla K, Shrestha PS, Costello AM. Gestational age specific birth weight centiles in Nepal. J Nep Med Assoc. 1999;38:29-34.

6. Manandhar DS, Rajbhandari S, Pal D, Costello AM. Anthropometry of the term newborn and postnatal mother in Nepal. J Nep Med Assoc. 1997;35:150 -7.

7. Ghai OP, Gupta P. Newborn infants. In: Gupta P, Paul VK (editors). Ghai Essential Pediatrics, 7th ed. New Delhi (India): CBS Publications; 2010. pp 96-103.

8. United Nations Children's Fund (UNICEF). The State of the World's Children 2004. New York; UNICEF: 2003.
9. National Neonatology Forum of India. National Neonatal Perinatal Database-Report for year 2000. New Delhi: National Neonatology Forum, India; 2001.

10. Yajnik CS, Fall CHD, Coyaji KJ, Hirve SS, S Rao, Barker DJP, et al. Neonatal anthropometry: the thin-fat Indian baby, the Pune maternal nutrition study, India. Int J Obesity. 2003;27:173-80.

11. Mathai M, Jacob S, Karthikeyan NG. Birth weight standards for south Indian babies. Indian Pediatr. 1996 Mar;203(33):203-9.

12. Dhar B, Mowlah G, Nahar S, Islam N. Birth weight status of newborns and its relationship with other anthropometric parameters in a Public maternity hospital in Dhaka, Bangladesh. J Health Popul Nutr. 2002 Mar;20(1):36-41.

13. Haque F, Hussain AMZ. Detection of low birth weight new born babies by anthropometric measurements in Bangladesh. Indian J Pediatr. 1991;58:223-31.

14. Najmi SR. Distribution of Birth weights of Hospital Born Pakistani Infants. J Pakistan Med Assoc. 2000 Apr;50(4):121-4.

15. World Health Organization. Multicentre study on low birth weight and infant mortality in India, Nepal and Sri Lanka. New Delhi: Southeast Asia Regional Office, World Health Organization; 1994. 78 p.

16. Aryal DR, Gurung R, Misra S, Khanal P, Pradhan A, Gurubacharya SM. Intrauterine growth curves for singleton live babies in Paropakar maternity and women's hospital in Nepal. J Nepal Health Res Counc. 2012 Jan;10(20):160-6. 